\title{
Middelloopbaan-ontwikkeling deur spirituele lewenstylafrigting: Verkennende teoretiese perspektiewe
}

\begin{abstract}
Authors:
Madelein C. Fourie ${ }^{1}$

Jan Albert van den Berg

Affiliations:

${ }^{1}$ Department of Practical

Theology, University of the

Free State, South Africa

Note:

Dr Madelein Fourie is a Research Associate in the Department of Practical

Theology, University of the Free State, South Africa.

This article stems from the doctoral dissertation of $\mathrm{Dr}$

Fourie with Prof. Jan Albert van den Berg as supervisor.

This article is published in the section Practical Theology of the Society for Practical Theology in South Africa.
\end{abstract}

Correspondence to:

Jan Albert van den Berg

Email:

vdbergja@ufs.ac.za

Postal address:

PO Box 100985, Brandhof

9324, South Africa

Dates:

Received: 26 Mar. 2012

Accepted: 11 July 2012

Published: 27 Feb. 2013

How to cite his article:

Fourie, M.C. \& Van den Berg, J.A., 2013, 'Middelloopbaanontwikkeling deur spirituele lewenstylafrigting: Verkennende teoretiese perspektiewe', HTS Teologiese Studies/ Theological Studies 69(2), Art. \#1246, 9 pages. http://dx.doi.org/10.4102/ hts.v69i2.1246

\section{Copyright:}

(C) 2013. The Authors.

Licensee: AOSIS

OpenJournals. This work

is licensed under the

Creative Commons

Attribution License.

\section{Read online:}

Middle-career development through spiritual lifestyle coaching: Preliminary theoretical perspectives. This study bases itself in the epistemological and methodological development of a broad and interdisciplinary dialogue where various voices in the form of different domains converse in order to establish an integrated whole. The research contributes to the actual corporative question regarding spirituality in the workplace, specifically aimed at the individual in the middle-career phase. This phase is characterised as a re-evaluation period aimed at personal and professional growth. A shift in emphasis to the meaning and sense of work is linked to spiritual intelligence as spirituality can be described and understood as a type of intelligence. The study shows that the middle-career experience provides opportunity for an altered future view. Lifestyle coaching serves as facilitating process and offers guidance in answering existential questions which are included in the spiritual. The probable outcome promises to add meaning as a manifesting component in a dynamic and transforming life strategy.

\section{Ouverture}

Musiek is die kuns om in klank te dink (Oxtoby 1964:11). Een vergestalting daarvan is ' $n$ drama wat volledig getoonset is en as 'n opera bekend staan (Oxtoby 1964:53). 'n Opera is ' $n$ 'drama set to music' (Kennedy 1980:463). In hierdie studie speel opera as metafoor 'n belangrike rol omrede dit as brug dien en ruimte bied vir die aanwesigheid van 'n interdissiplinêre aksent waar die navorsing beoog om sélf libretto te word. 'n Libretto behels die teks van 'n werk wat gesing word, in die besonder 'n opera (Kennedy 1980:370), en kundiges verwys ook daarna as die 'book of words' (Scholes 1970:573). Benewens die konseptuele struktuur wat die gebruik van 'n metafoor bied, bied dit ook die geleentheid om 'n eie 'boek van woorde' te skep. Hierin word nie net die voorlopigheid van die voorgestelde teks beklemtoon nie, maar dit vind uitdrukking in hoorbare, gespreksvoering met 'n heenwysing na interdissiplinariteit. Die klem word dus hiér op die skepping en die konstruering van 'n nuut geskryfde libretto (operateks) geplaas.

Ter aanvang van die studie word aansluiting gevind by die beeld van die ouverture wat die begin of opening van die opera aandui. Dit stel die luisteraar voor aan al die melodieë en stemme wat tydens die interdissiplinêre gesprek, met die beweging tussen praktyk en teorie, gehoor sal word.

Die titelbenaming van hierdie navorsing veronderstel drie domeine, naamlik middelloopbaanontwikkeling, spiritualiteit en lewenstylafrigting. Elk verteenwoordig 'n spesifieke studieveld. Middelloopbaanontwikkeling is deel van die bedryfsielkunde en meer spesifiek die beroepsielkunde (Greenhaus, Callanan \& Godshalk 2010). Spiritualiteit vind neerslag in die religieuse (Louw 2005:133-147; Bjorklund \& Bee 2008:267-291) asook binne die ekonomiese en bestuurswetenskappe wanneer dit vanuit 'n werkplekperspektief beskou word (Smith 2006). Lewenstylafrigting is deel van afrigtingsielkunde (Grant 2003; Grant \& Zackon 2004) en is in enige veld van waarde. Die praktiese teologie is ' $n$ vierde verteenwoordigende domein en word nie direk in die titel verwoord nie omdat die klem op spiritualiteit, wat reeds verteenwoordig word, 'n alles-insluitende lewenswyse voor God veronderstel. Die verkenning van die omvang van die praktiese teologie as studieveld bied egter ruimte om tot ' $n$ verstaan van die web van die lewe te kom met spiritualiteit wat aksente van lewenskuns en lewensvaardighede toon en intens met God se teenwoordigheid rekening hou.

Daar is ' $n$ toenemende klem op die ontwikkeling van die spirituele in die werkplek, wat 'n integrering van domeine vereis. Daarmee saam word die werkende mens gekonfronteer met loopbaanstadia wat bepaalde eise stel. Dit bring die uitdaging aangaande middelloopbaanontwikkeling na vore wat verder uitmond in die vraag: Kan lewenstylafrigting as fasiliteringsproses leiding bied in die beantwoording van eksistensiële vrae wat in die spirituele opgesluit is?

Die agtergrond tot die navorsing word aan die hand van die vier domeine in 'n interdissiplinêre gesprek bespreek. Alhoewel hierdie vier stemme die hoofkarakters van die libretto vorm, word ook aksente en nuanses in medekarakters vergestalt en in die onderafdelings van domeine gehoor. 


\section{Die eerste bedryf: Die bekendstelling Die begin}

Dat leer vir oorlewing en voortgesette welstand belangrik is, kan nie genoegsaam beklemtoon word nie. Leer moet lewenslank plaasvind en word deur Klasen en Clutterbuck (2002) benadruk:

No-one can afford to stop learning when they leave school. To maintain their employability, people will need to keep learning at different stages throughout their lives...Learning is not just about employability. New research ... show(s) that ... learning improved ... enjoyment of life ... self-confidence ... health. (bl. 4)

Die sielkunde definieer leer as enige relatief permanente verandering in gedrag of kennis wat op ondervinding gegrond is. Die grootste gedeelte van gedrag is die resultaat van leerprosesse (Louw \& Edwards 2005:211). Gedrag kan aangeleer word, maar deur nuwe maniere van dink en doen, kan gedrag ook afgeleer word. Leer is vir alle aspekte van die lewe belangrik en geld vir sosiale, emosionele en inderdaad ook fisiese ontwikkeling.

Uit die repertorium van leer en ontwikkelingsmetodes blyk afrigting, en spesifiek lewenstylafrigting, 'n individuele leerproses met lewensveranderende uitkomste te wees. Rogers (2004:80) merk op: 'Our prime task as coaches is to facilitate learning for the client.' Hoewel min empiriese navorsing omtrent die doeltreffendheid van lewenstylafrigting beskikbaar is, word afrigting as 'n praktyk met 'n grenslose skopus beskou (Grant 2003:254).

Die bevolkingsontploffing van middeljarige volwassenes asook toenemende kennis aangaande hierdie lewensfase het gelei tot die identifisering van die middeljare as 'n lewensloop-segment wat in eie reg die moeite werd is om te bestudeer. Die 'baby-boom'-generasie, verteenwoordigend van diegene wat tussen 1946 en 1964 gebore is, beweeg tans in rekordgetalle deur die middeljare (Lachman 2004:308-309) en word as een van die fokus-domeine in die studie aangedui.

In aansluiting hierby word spirituele intelligensie as 'n moontlike antwoord vir sinvolle ontwikkeling en ervaring tydens die verwarrende middelloopbaanfase geïdentifiseer, hoewel dit nog 'n nuwe veld is. Die presiese neerpen van spiritualiteit in een werkbare definisie is moeilik weens die diverse verwysingsraamwerke waarbinne dit geplaas word (Miller 2000:6; West 2000:7; Carette \& King 2005:31). Een van die verwysingsraamwerke behels 'werkplekspiritualiteit' en geniet tans wêreldwyd aandag, met die klemverskuiwing na werk as betekenis- en sinvol (Hicks 2003:27; Smith 2006:6).

Binne praktiese teologie as studieveld kan ' $n$ interdissiplinêre gesprek aangemoedig word. Aksente vanuit onder andere die pastoraat word ook gehoor, waar dit die verstaan van God met menslike reële ervarings wil verbind sodat eksistensiële sin ontdek kan word (Louw 1999:3). Die pastoraat het die taak om die mens en wêreld sodanig te verstaan dat kontekste met die evangelie in aanraking gebring word (Bons-Storm 1989:85; Louw 1999:23).

\section{Interdissiplinêre gesprek}

Waar dissiplines aanvanklik deur rigiede, vasgestelde grensafbakening onderskei en gekenmerk is, is daar tans ' $n$ wegbeweeg van rigiditeit na vloeibaarheid en deursigtigheid. Die rigiede grensafbakening tussen dissiplines word afgebreek om vir 'n veranderde prentjie van 'blurred genres' plek te maak (Geertz 1980:165-166; Giri 2002:104). In hierdie verband onderstreep Giri (2004:346) die aannames van Katz (1995) wanneer sy die volgende opmerk:

This blurring of disciplinary boundaries is easily noticeable in the way new disciplines and sub-disciplines are emerging which embody the limits of conventional disciplinary boundaries and the quest for a new mode of engagement, which cuts across various disciplines. (bl. 871-872)

Van Huyssteen (2006:9) benadruk dat daar in elke interdissiplinêre gesprek verskillende diskoerse teenwoordig is, gekenmerk deur radikale diverse perspektiewe, asook onderskeibare ondersoekmetodes, met die bekentenis dat 'they cannot be reduced to each other or derived from each other'. Die uitdaging is daarin geleë om aan te toon dat dit juis tússen die grenslyne van dissiplines is waar 'new and exciting discoveries take place' (Van Huyssteen 2006:9). 'n Interdissiplinêre benadering vra dus om 'n werkswyse wat 'n geïntegreerde geheel met 'n holistiese begrip ten doel wil stel (Van Wyk 1997:77; Van der Ven 1993:89-93; Van Huyssteen 2006:9).

Ten einde in die epistemologiese en metodologiese ontwikkeling van só 'n voorgestelde breë en interdissiplinêre wetenskaplike gesprek tuis te kom, is dit vervolgens nodig om kennis te neem van wat met die interdissiplinêre gesprek as diskoers veronderstel word.

Die interdissiplinêre gesprek behels volgens Van Huyssteen (2006:9) 'n poging 'to bring together disciplines or reasoning strategies that may have widely different points of reference, different epistemological foci, and different experiential resources'. Die 'fitting together' veronderstel 'n komplekse, veelvlakkige, transversale proses wat nie binne die grense van enige gegewe dissipline plaasvind nie, 'but within the transversal spaces between disciplines' (Van Huyssteen 2006:9). Van den Berg (2010:16) wys daarop dat navorsers sensitief daarvoor moet wees om nie verskillende dissiplines in 'n afgedwonge gesprek in te forseer nie. Hierin word ag geslaan op die oproep van Osmer (2006:343) wat tereg vra om 'articulating and justifying the principle of selection in a transversal model of interdisciplinarity,' ten einde daarop te kan wys 'why specific persons or perspectives are engaged as interdisciplinary dialogue partners in a particular book or research project'.

In die ouverture, is die deelnemers aan hierdie gesprek vlugtig voorgestel. Dit is ook belangrik om ter motivering van die verhouding daarop te dui dat hierdie gespreksgenote mekaar akkommodeer sover dit perspektiewe en insigte vanuit die pastoraat, ontwikkelingsielkunde en die ontwikkelende veld van afrigting en spesifiek lewenstylafrigting betref. 


\section{Navorsingsoektog}

Hierdie navorsing handel oor 'n soektog in 'n poging om 'n nuwe libretto te skryf en nuwe ontdekkings met bepaalde perspektiewe te maak. Die navorsingsproses word aan die skryf van 'n storie of die skep van 'n boek gelyk gestel; in hierdie geval, is die skryf van 'n operateks of libretto die metafoor. Navorsing skep 'n eie storie, met nuwe moontlikhede, wat vir die stimulering van 'n nuwe storie en nuwe navorsing 'oop eindes' veronderstel (Müller, Van Deventer \& Human 2001:87). Daarom is daar voortdurende beweging in hierdie navorsing - vanaf die eerste bedryf na die laaste en vyfde bedryf - wat nie net by die opera-metafoor aansluit nie, maar ook op'n bepaalde interdissiplinêre gesprek tussen verskillende domeine dui. In die navorsingsoektog word aansluiting gevind by Browning (1991:84), wat 'n voortdurende en sirkulêre beweging tussen praktykteorie-praktyk veronderstel. Hierdie beweging word in die sogenaamde ABDCE-navorsingsmodel uitgedruk omrede dit verder vanuit 'n narratief geïnformeerde werkswyse ontwikkel is (Müller 2001:64-70; Müller et al. 2001:78-88). Hierdie werkswyse veronderstel nie ' $n$ tradisionele ontwerp waar liniêre belyning in terme van probleemformulering, doelwitstelling en vooropgestelde oplossings die navorsing lei nie.

Hierdie studie word vanuit 'n postmoderne, sosiaalkonstruktivistiese diskoers onderneem. Dit gaan om 'n 'gedeelde konstruk binne 'n interpreterende gemeenskap' (Müller 1996:33). Die navorsing word binne die narratiefhermeneutiese navorsingsbenadering geplaas en die keuse word gemaak om kwalitatiewe navorsing te gebruik.

Die waarde van hierdie navorsing is ingebed in die uniekheid van eiesoortige stemme wat deur interdissiplinariteit en kruisinformering tot 'n geïntegreerde geheel gestel word. Die deelnemende domeine en gespreksgenote aan hiérdie betrokke interdissiplinêre gesprek word vervolgens aan bod gestel.

\section{Die tweede bedryf: Die praktiese teologie}

Die praktiese teologie is ' $n$ verteenwoordigende domein en deelnemende gespreksgenoot. Alhoewel dit nie direk in die studie-titel verwoord word nie, toon spiritualiteit wel aksente van lewenskuns en lewensvaardighede wat intens met die teenwoordigheid van God rekening hou.

\section{Die praktiese teologie}

Don Browning skryf die volgende in die voorwoord tot die publikasie van Willows en Swinton (2000) se Spiritual dimensions of pastoral care: Practical theology in a multidisciplinary context:

The past forty years or so have witnessed the emergence of a fresh vision of practical theology as an exciting, vibrant, multidisciplinary way of doing theology that incorporates and challenges both accepted theory and forms of practice. (bl. 9)
Dit is daarom nie akkuraat om die prakties-teologiese veld as alleenlik 'concerned with application, with helpful techniques and skills applied to the life of the church,' te sien nie (Osmer 2008:ix). Volgens Swinton en Mowat (2006:v) is die praktiese teologie 'an intricate and complex enterprise' en behels dit nie 'n enkele, gestandaardiseerde wyse 'of doing practical theology' met enige 'particular wing of theology' wat eienaarskap daarvan opeis nie.

Cilliers (2009) redeneer dat die praktiese teologie te make het:

met die praxis van God se heilshandelinge, wat in bepaalde ontmoetingsgestaltes na vore tree. Praktiese teologie bestudeer die wyse waarop mense uit hierdie ontmoetingsgestaltes sin probeer maak - daarom rus dit op 'n eksistensiële hermeneutiek. (bl. 628)

Die pastoraat is in die vorm van ontmoetingsgebeure hierby betrokke, waar die term ontmoeting 'n wedersydse en wederkerige kontak en dialoog tussen God en mens impliseer (Louw 1999:35).

'n Nuwe verstaan en ontwikkeling het daarom in die praktiese teologie sigbaar geraak en kan soos volg opgesom word (Osmer 2006):

Practical theology constructs action-guiding theories of Christian praxis in particular social contexts based on four interrelated forms of research and scholarship - the descriptive-empirical, the interpretive, the normative, and the pragmatic. (bl. 328)

In die verrekening van hierdie definisie is dit duidelik dat die praxis-terrein vir die praktiese teologie van besondere belang is. Die praktiese teologie is 'n praktykgebaseerde dissipline waarin 'aksie' geïmpliseer word (Willows \& Swinton 2000:14) en waarin vier kerntake geïdentifiseer word, naamlik die deskriptiewe-empiriese taak, die interpreterende taak; die normatiewe taak en die pragmatiese taak (Osmer 2006:328-329; Osmer \& Schweitzer 2003:1-4; Osmer 2008:4-12). Die wedersyds beïnvloedende verhouding van hierdie vier take kan met die beeld van 'n hermeneutiese sirkel gekonseptualiseer word waar elkeen van die take deel is van 'n groter, interverwante geheel. Osmer (2006:330) stel dit duidelik dat, hoewel ander velde een of twee van die take ten uitvoer bring, dit slegs die praktiese teologie is wat al vier take beoefen.

\section{Modelle vir' $n$ interdissiplinêre gesprek in die praktiese teologie}

Ten einde ' $n$ interdissiplinêre gesprek in die praktiese teologie te fasiliteer, word drie moontlike modelle onderskei, naamlik die korrelasie-, die transformasie- en die transversale benadering (Osmer 2006:339-342, 2008:164-173). Die derde benadering tot die interdissiplinêre gesprek blyk die beste wyse te bied waarop die diskoers tussen die praktiese teologie en die ander gespreksgenote geakkommodeer kan word. Die rasionaal daarvoor is dat hierdie benadering die oorsteek van grenslyne tussen verskillende dissiplines moontlik maak ten einde 'n multidissiplinêre, holistiese en veelvlakkige werkswyse te bied. 
Dissiplines word beskou as 'networks that transverse one another and share the common resources of rationality' (Osmer 2008:172). Transversaliteit word beskou as persoon- en perspektiefspesifiek, waar dit areas van oorvleueling en divergensie in 'n dialoog tussen spesifieke mense of perspektiewe ondersoek (Osmer 2008:172).

In hierdie navorsing word vir 'n 'postfoundational' praktiese teologie binne die ruimte van postmoderniteit gekies, met transversale rasionaliteit as werkswyse. Müller (2008:887) stel dit dat 'n 'postfoundational' praktiese teologie na die gemeenskaplike in die menslike denkprosesse soek ten einde 'n goed-verantwoorde epistemologie daar te stel wat die toets van intergroepgesprekvoering kan deurstaan.

\section{Mens-beskouing}

Die pastorale ontmoeting word beïnvloed deur die beskouing wat die navorser jeens die mens handhaaf. Dit is daarom dat Louw (1999:152) van mening is dat die grondliggende beskouing van die mens vir enige beleid of strategie bepalend is. In die formulering van ' $n$ antropologie word aangesluit by Van den Berg (2008:122) wat vir 'n beliggaamde-sielantropologie kies. Tradisionele teologiese antropologieë het aanvanklik min of geen erkenning aan die betekenis van die liggaamlike gegee nie. In die werkplek het die tradisionele tweedeling tussen liggaam en gees, volgens Van den Berg (2010:110), geen relevante betekenis nie.

In navorsing aangaande 'spiritualiteit' in die werkplek het Mitroff en Denton (1999) bevind dat dit om die 'hele persoon' gaan, met individue wat verkies om die hele self na die werkplek te bring. Die navorsers merk in dié verband op: 'It is clear from the total context of the interviews that a decisive majority wished to be able to express and develop their complete self at work' (Mitroff \& Denton 1999:85-86). Smith (2006:1) voeg hierby dat werkers daarop aandring dat hulle spiritualiteit, net soos hulle intelligensie, in die werkplek verwelkom moet word.

\section{Spirituele betekenis en sinbelewing}

Ten einde laaste het die pastoraat ten doel om te 'komen tot verstaan: verstaan van zichzelf, verstaan van elkaar, in het perspectief van het evangelie, opdat mensen weer weten, waartoe zij bestaan' (Bons-Storm 1989:9). Dit wil ons 'verstaan van God verbind met reële menslike ervarings sodat ons menslike bestaan of eksistensiële sin mag ontdek' (Louw 1999:3) en het ten doel 'to develop the theological lens through which we... can understand the human condition and organize an effective pastoral response' (Lester 1995:2).

Dat spiritualiteit 'n belangrike rol in die erkenning van die realiteit speel, word bevestig in die opmerking van Sherburne (2008:104) dat 'spirituality provides the bridge between these seemingly contradictory purposes as one seeks and embraces a changing reality'. Voeg daarby dat Wink en Dillon (2002:91) op 'n toename in spiritualiteit gedurende die middel- en laatvolwasse lewensfase wys, en dit blyk duidelik dat spiritualiteit tot ' $n$ integrasie van die verskeie aspekte van menswees lei (Louw 1999):

'n Integrale spiritualiteit moet die kwaliteit van menswaardigheid sodanig verbeter dat die teenwoordigheid van God 'n bydrae tot die sin van menslike bestaan en die kwessie van humaniteit lewer; dit moet die innerlike en die private verbind met die lewe, die sosiale konteks en publieke karakter van die mens se bestaan. (bl. 236)

Vervolgens word die derde bedryf, met middelloopbaanontwikkeling as gespreksgenoot, aan die woord gestel. Die lewensloopbenadering en loopbaanfases is vergestaltende perspektiewe in hierdie bedryf.

\section{Die derde bedryf: Middelloopbaanontwikkeling}

Die middeljare, 'the afternoon of life,' soos Jung (1933:112) in The stages of life daarna verwys, het 'n fase van groot belang vir lewensloopnavorsers geword. Die middeljare dien as 'n belangrike voorbereidingsfase in die oorgang na bejaardheid of 'the evening of life.' Vervolgens word die implikasies hiervan met loopbaanontwikkeling in verband gebring.

\section{Volwasse ontwikkeling}

Dit blyk dat menslike ontwikkeling reeds vanaf die vroegste tye die nodige erkenning ontvang het. Hier word verwys na insig in ' $n$ relatief bepaalbare reeks periodes of fases wat tot die vorming van die mens se persoonlikheid en intelligensie bydra (Louw \& Edwards 2005:6). Hierdie ontwikkelingsfases strek oor die mens se totale lewensloop, vanaf bevrugting tot die dood, en die wetenskap wat dit bestudeer, staan as die ontwikkelingsielkunde bekend (Bjorklund \& Bee 2008:4; Louw \& Edwards 2005:451). Ontwikkeling veronderstel verandering, wat per implikasie op 'n verskil in iets of iemand dui en wat met tydsverloop gepaardgaan (Papalia et al. 2007:4). In samehang veronderstel volwasse ontwikkeling 'n kontinue proses en dit kan in drie periodes verdeel word (Atchley \& Barasch 2004:8-9; Louw \& Ewards 2005:493; Papalia et al. 2007:8), naamlik:

- vroegvolwassenheid - ongeveer 20-40 jaar

- middelvolwassenheid - ongeveer 40-65 jaar

- laatvolwassenheid - vanaf ongeveer 65-jarige ouderdom.

Die vraag ontstaan of loopbane op dieselfde relatief ordelike wyse ontwikkel? Greenhaus, Callanan en Godshalk (2000:108) stel dit dat verandering 'in the nature of career motivation are likely to occur over the course of an employee's life'. Hulle insig in taak- en ontwikkelingsimplikasies tydens die verskillende loopbaanfases kan individue in staat stel om hulle eie loopbane meer doeltreffend te bestuur (Greenhaus et al. 2010:28).

\section{Die ontwikkeling van loopbane}

'n Loopbaan word gedefinieer as die patroon van werksverwante ervaringe wat die lewensloop van 'n individu oorspan (Greenhaus et al. 2010:10). Die ontwikkeling van loopbane het verandering ondergaan dienooreenkomstig 
die rol wat organisasies in werknemers se loopbane gespeel het (Hall 1996:8-16; Eby, Butts \& Lockwood 2003:689-708). Dit het ontwikkel vanaf paternalisme, waar organisasies volle verantwoordelikheid vir werknemers se loopbane aanvaar het, tot ondersteuning van individue, waar persoonlike verantwoordelikheid vir eie toekomstige loopbaanontwikkeling beklemtoon word. Dus behels loopbaanontwikkeling twee aparte maar ook onderling verwante funksies, naamlik loopbaanbeplanning, wat 'n individuele proses is, en loopbaanbestuur, wat ' $n$ institusionele proses is (Gutteridge 1986:54-56; Robbins 2001:483).

Greenhaus et al. (2010:13) definieer loopbaanontwikkeling as 'n voortdurende proses waar individue deur 'n reeks stadia beweeg, wat elk deur 'n relatief unieke stel kwessies, temas en take gekenmerk word. Hierdie definisie demonstreer kruisbestuiwing tussen loopbaanbestuur en -ontwikkeling.

\section{Die fases van loopbaanontwikkeling}

Greenhaus et al. (2010:34-37) kategoriseer die ontwikkeling van loopbane in vier stadia. Hulle siening is eerstens op die literatuur aangaande loopbaanontwikkeling en tweedens op Levinson se siening oor volwasse lewensontwikkeling gebaseer. Hulle verkies om loopbaanstadia rondom geraamde ouderdomme te organiseer, nie omrede hulle van mening is dat dit die beste wyse is om loopbaanontwikkeling te beskou nie, maar omrede dit ' $n$ betekenisvolle struktuur aan hulle kennis van loopbane verleen.

Die middelloopbaanfase word ingelei deur die middeljareoorgang, wat as brug tussen die vroeë en middelvolwassenheid dien. Hierdie tydperk word gekenmerk deur 'n herevaluering van leefstyl en eise met moontlike mindere of radikale veranderinge. 'n Nuwe leefstyl kan moontlik die uitkoms wees met spesifieke werksverwante kwessies wat gekonfronteer moet word (Greenhaus et al. 2010:36).

In Tabel 1 (Greenhaus et al. 2010:35) word die vier stadia kortliks bespreek. Daar word in die vorm van 'n geskakeerde gedeelte spesifiek verwys na die derde stadium, naamlik die middelloopbaanfase, wat die fokuspunt van hierdie betrokke navorsing is.

\section{Die middelloopbaanfase}

Die middelloopbaanfase veronderstel die ouderdomsgroep tussen 40 en 55 jaar (Greenhaus et al. 2010:230). Twee belangrike veranderlikes kenmerk hierdie fase, naamlik die konfrontering van die middeljarekrisis en die behoud van produktiwiteitsvlakke (Greenhaus et al. 2010:231).
Die konfrontering van die middeljarekrisis behels selfondersoek, 'n herevaluering van oortuigings en waardes, heraanpassing by fisiese veranderinge en 'n hersiening van lewenstyl, loopbaanrigting en prioriteite. Dit behels ook 'n herondersoek van ambisie, drome wat bereik is en die belangrikheid van 'n loopbaan (Collins 2005:220; Greenhaus et al. 2010:230). Die belangrikheid van werk is nie net geleë in die inkomste wat dit genereer nie, maar dit verskaf 'n lewensraamwerk, 'n afbakening van dae, weke en maande. Dit bepaal ook mense se interaksie met andere, asook selfagting, identiteit en status in die samelewing (Raddon 2005:5-6; Whitbourne 2007:246).

Die tweede veranderlike, die behoud van produktiwiteitsvlakke, konfronteer die gemaksone rondom vaardigheid. Twee middelloopbaanervaringe kan produktiwiteit affekteer, naamlik die loopbaanplato en loopbaanveroudering. Die loopbaanplato word beskou as 'n tyd in 'n loopbaan waar die waarskynlikheid van addisionele hiërargiese bevordering laag is. Loopbaanveroudering verwys na ' $n$ tekort aan nuwe kennis en werksvaardighede, wat sodoende effektiewe, mededingende, volhoubare funksionering beïnvloed (Betz 2003:207-209; Bown-Wilson \& Parry 2009:76). Stagnering en 'n mentaliteit waar die loopbaan slegs in stand gehou word, is ' $n$ bedreiging vir hierdie fase. Vaardigheidsontwikkeling word vereis, asook genoegsame outonomie om hierdie nuut aangeleerde vaardighede toe te pas (Greenhaus et al. 2010:233-238).

Merriam, Caffarella en Baumgartner (2007:199) wys daarop dat ontwikkelingsielkundiges tot so ver terug as Jung beweer dat volwassenes, wanneer hulle die middeljare bereik, na binne keer en diep oor die betekenis van die lewe en spirituele aspekte van die self nadink. Die vraag na betekenis en sinbelewing gedurende die middeljare, en spesifiek tydens die middelloopbaanfase, behels die integrasie van verskeie konstrukte. Dit hou ook verband met die intelligensie wat werknemers na die werkplek bring, asook hulle bewussyn van die volledige self, wat 'n spirituele dimensie insluit. Vervolgens word die volgende stem in die opera, naamlik spirituele intelligensie, gehoor.

\section{Die vierde bedryf: Spirituele intelligensie}

Die studie deur Kinjerski en Skrypnek (2008) lewer vanuit hulle waarneming van respondente tydens die middeljare treffende insigte. Spiritualiteit word deur respondente as 'n middeljareverskynsel erken en dit blyk dat spiritualiteitsontwikkeling gedurende hierdie lewensfase 'n hoogtepunt bereik.

TABEL 1: Greenhaus se vier stadia van loopbaanontwikkeling.

\begin{tabular}{|c|c|c|}
\hline Stadium & Tipiese ouderdomspelling & Belangrikste take \\
\hline Beroeps- en organisatoriese keuse & $18-25$ & $\begin{array}{l}\text { Ontwikkel beroepselfbeeld, assesseer alternatiewe beroepe, ontwikkel aanvanklike beroepskeuse, } \\
\text { gaan voort met die nodige studie, werf werksaanbiedinge van geskikte organisasies. }\end{array}$ \\
\hline Vroeë loopbaan & $25-40$ & $\begin{array}{l}\text { Leer werk, leer organisatoriese reëls en norme, pas aan in gekose beroep en organisasie, verhoog } \\
\text { bevoegdheid, streef loopbaandoelwitte na. }\end{array}$ \\
\hline Middelloopbaan & $40-55$ & $\begin{array}{l}\text { Herevalueer die vroeë loopbaan en vroeë volwassenheid, herbevestig of pas loopbaandoelwitte aan, } \\
\text { maak keuses geskik vir die middelvolwasse jare, behou werksproduktiwiteit. }\end{array}$ \\
\hline Laat loopbaan & 55 - aftrede & Behou werksproduktiwiteit, behou selfbeeld, voorbereiding vir effektiewe aftrede. \\
\hline
\end{tabular}

Bron: Greenhaus, J.H., Callanan, G.A. \& Godshalk, V.M., 2010, Career management, 4th edn., Sage Publications Inc., Thousand Oaks, CA 


\section{Spiritualiteit en betekenis toegevoeg}

Skrywers vind dit moeilik om spiritualiteit in een werkbare en aanneemlike definisie saam te vat (Miller 2000:6; West 2000:7; Carette \& King 2005:31). Elke akademiese veld wat deur spiritualiteit kruisbestuif word, definieer die term op 'n eiesoortige wyse. Hierdie term bied weerstand teen 'n presiese definiëring, enersyds vanweë die verskeidenheid wyses waarop dit aangewend word en andersyds vanweë die geskilpunt binne dissiplines in 'n poging om dit binne ' $n$ definitiewe raamwerk te plaas.

In die lig van die voorafgaande en gedagtig aan die navorsing van Mohamed et al. (2004:103) kom ons tot die slotsom dat spiritualiteit tot vyf dimensies behoort, naamlik (1) oortuigings, houdings en persepsies; (2) transendentale ervaringe; (3) sin en betekenis vir menslike bestaan; (4) geloof in die paranormale en (5) religieuse gedrag en praktyk.

Dit is duidelik dat elke definisie op ' $n$ bepaalde faset van spiritualiteit fokus. Die veelheid spirituele fasette is dus ' $n$ aanduiding dat spiritualiteit ' $n$ multidimensionele fenomeen is (Miller 2000:6).

\section{Spiritualiteit in die werkplek}

Die onderwerp 'spiritualiteit in die werkplek' geniet tans wêreldwyd aandag en is besonder aktueel (Hicks 2003:27; Marques, Dhiman \& King 2009:x). Die aantal boeke, tydskrifte, webwerwe, beeldmateriaal, opleiding- en afrigtingseminare wat tans oor werkplekspiritualiteit beskikbaar is, bevestig dit (Giacalone, Jurkiewicz \& Fry 2005:515-516; Marques, Dhiman \& King 2007:8).

Die ontwikkeling van korporatiewe belangstelling in spiritualiteit word egter nie as 'n tendens beskou nie, maar as 'n beweging. Spiritualiteit in die werkplek is nie 'n enkele of eenmalige, georganiseerde beweging nie. Dit is ' $n$ basisbeweging met ' $n$ klemverskuiwing na werk as betekenisvol en sinvol (Hicks 2003:27; Smith 2006:6). Werknemers is op soek na sin en betekenis in die werkplek wat veel meer as slegs die maak van geld behels (Van der Walt, Du Plessis \& Barker 2006:264). Dit is vir werkers van belang dat hulle spiritualiteit in die werkplek verwelkom word (Smith 2006:1).

\section{Spirituele intelligensie}

Kan die strewe na sin en betekenis binne 'n organisatoriese opset moontlik met spirituele intelligensie in verband gebring word? Zohar en Marshall, die skrywers van Spiritual intelligence (2000) en Spiritual capital (2004) is van mening dat die soeke na betekenis en sinbelewing moontlik met spirituele intelligensie in verband gebring kan word.

Zohar en Marshall (2000) definieer spirituele intelligensie as die vermoë:

with which we address and solve problems of meaning and value, the intelligence with which we can place our actions and our lives in a wider, richer, meaning-giving context, the intelligence with which we can assess that one course of action or one life-path is more meaningful than another. (bl. 3, 4)
Intelligensie bied moontlikhede rondom probleemoplossing. Vandaar die aanname dat spirituele intelligensie probleme van betekenis kan oplos, met die vermoë om die uitkomste in die breë lewenskonteks van 'n ryker begrip te kan plaas. Spirituele intelligensie veronderstel dus 'n nuwe domein vir intellektuele aksie. Die volgende vraag wat dus aan bod gestel word, is of lewenstylafrigting deur middel van 'n fasiliteringsproses 'n moontlike bydrae kan lewer?

\section{Die vyfde bedryf: Lewenstylafrigting}

Die voortsetting van lewensverbetering, persoonlike ontwikkeling en die ontginning van betekenis het aanvanklik by die vroeë Griekse samelewing begin. Dit word weerspieël in Socrates se bekende aanhaling: 'The unexamined life is not worth living' (Williams \& Menendez 2007:xv). Sedertdien is verskeie wyses ontwikkel om in die ondersoek na die menslike lewe van hulp te wees.

\section{Afrigting}

Afrigting (coaching) is ' $\mathrm{n}$ benadering wat toenemend groei in gewildheid (Hamlin, Ellinger \& Beattie 2009:13). Afrigting en afrigtingsielkunde bied 'n potensiële platvorm vir die fasilitering van individuele, organisatoriese en sosiale verandering (Grant \& Cavanagh 2007b:239). Dit blyk dat individue na tegnieke en prosesse soek wat lewenservaring sal verhoog en persoonlike ontwikkeling sal fasiliteer (Grant 2003:253; Rice 2007:501-503). Weens die onbekendheid en varsheid van hierdie konsep word daar vir 'n oomblik stilgestaan om verdere perspektiewe te ontgin.

Tot en met die laat 1980's was die term 'afrigting' en die literatuur daaromtrent hoofsaaklik beperk tot die studie van sportprestasieverhoging beperk (Spence 2007:260; McCluskey 2008:266). Praktisyns in drie velde, naamlik besigheidskonsultering, berading en psigoterapie en die persoonlikegroei-beweging het behoeftes rakende visie, kernwaardes, doelwitbereiking en spanbou ontwikkel. Afrigting was die moontlike antwoord, aangesien dit proaktiewe, visionêr-gedrewe aksies en groei-oriëntasie en lewensvolheid veronderstel. Leonard het hierdie konsep verder uitgebrei en word as die 'vader' van lewenstylafrigting beskou (Vilas \& Corbin 2005:xi; McCluskey 2008:266). In 1994 stig hy die International Coach Federation (Wolcott 2001:11; McCluskey 2008:266). In die Suid-Afrikaanse konteks is dit die professionele organisasie, Coaches and Mentors Association of South Africa (COMENSA), wat dien as selfregulerende liggaam ten einde hoë standaarde rakende etiese kodes en aanbevole bevoegdheid te handhaaf.

Die afrigtingsbedryf, en spesifiek lewenstylafrigting, het sedert 1998 beduidend gegroei en geniet wydverspreide aandag in die populêre Westerse media (Grant 2003:254; Bachkirova, Cox \& Clutterbuck 2010:1). Honderde nuwe publikasies en ontwikkelingsprogramme dien as bewys hiervan (Grant 2006:15-16; De Haan 2008:21). Die vinnige groei van afrigting as domein is volgens Orem, Binkert en Clancy (2007:xv) 'n aanduiding van mense se fundamentele 
behoefte om die lewe en werk meer betekenisvol, gebalanseerd en holisties te maak. Afrigting word tans met elke veld van persoonlike en professionele strewes geassosieer.

\section{Definiëring van afrigting}

Veelvoudige definisies van afrigting bemoeilik die presiese definiëring van die domein. Die feit dat afrigting 'n ontluikende professie is waarin ooreengekome kernstandaarde en bevoegdheid ontbreek, is moontlik die rede waarom 'n definisie so kompleks is.

Die definisie, soos weergegee deur Hamlin et al. (2009), is 'n samestelling uit vyftien definisies. Die betrokke skrywers het 'n studie geloods om die konseptuele ooreenkomste en verskille in die veelvuldige beskrywings, definisies en variante van afrigting aan die orde te stel. Die uitkoms was die daarstelling van 'n breë afrigtingsdefinisie wat soos volg vertaal is (Hamlin et al. 2009):

Afrigting is ' $n$ helpende en fasiliteringsproses, wat individue, groepe/spanne en organisasies in staat stel om nuwe vaardighede te verkry, om bestaande vaardighede, bevoegdhede en prestasie te verbeter, asook die verhoging en versterking van persoonlike effektiwiteit, persoonlike ontwikkeling of persoonlike groei. (bl. 18, [Outeur se eie vertaling])

\section{Afrigting en ander dissiplines}

Die terme 'afrigting', en meer spesifiek 'lewenstylafrigting', word in verband gebring met ander dissiplines, wat tot veranderende gebruik lei. In die werkplek kan daarna verwys word as werkplekafrigting en doelwit-gefokusde afrigting (Grant \& Cavanagh 2007a:751-752). Die fiksheidsbedryf noem dit ook welsynsafrigting (Williams 2006:64-65). Op navorsingsvlak word daarna as bewysgebaseerde afrigting verwys (Grant 2008:54-55). Die voortdurende groeiende afrigtingsbedryf is afhanklik van gehalte afrigtingsopleiding en diens wat deur afrigtingspraktisyns gelewer word. Met die ontwikkeling, volwassewording en beweging tot professionaliteit van hierdie bedryf is daar 'n toenemende oproep tot die beklemtoning van bewysgebaseerde benaderings tot afrigting.

Om die verskil tussen afrigting en ander benaderings (waaronder ook pastorale berading vanuit 'n teologiese verwysingsraamwerk) te verstaan, is dit nodig om die verwante konsepte soos leierskap, berading, opleiding, konsultering en mentorskap te vergelyk. Tabel 2 voorsien 'n verduideliking van hierdie benaderings, asook hulle plek van oorsprong (Meyer \& Fourie 2004:7-8).

Afrigting deel vaardighede met ander verwante dissiplines en is belig ten einde die ooreenkomste en verskille te kon stel. Die onderskeid tussen afrigting, terapie, berading, mentorskap en opleiding is in die doel, proses en inhoud geleë. Die ooreenkomste wat hierdie dissiplines deel, behels uitstekende luistervaardighede en uitmuntende vraagstelling. Die kundigheid van afrigting lê in die toekoms as fokus, met doelwitte vir leer, verandering, groei en aksie.

Dit is belangrik om daarop te let dat afrigting nie terapie behels nie. Afrigting hanteer nie kliniese kwessies nie. Terapie word gebaseer op 'n reaktiewe model waar die verlede blootgelê word ten einde die teenswoordige te verbeter. Lewenstylafrigting daarenteen is proaktief, beginnende met die teenswoordige om sodoende 'n gefokusde toekomsblik te verkry. Terapie behels heling en kwessies rondom gebrokenheid, terwyl afrigting persoonlike groei, heelheid ('wholeness') en 'n reis na lewensvervulling veronderstel (Spence \& Grant 2007:186; McCluskey 2008:267-268).

\section{Lewenstylafrigting}

Lewenstylafrigting word gedefinieer as ' $n$ kollaboratiewe, oplossing-gefokusde, resultaatgeoriënteerde en sistematiese proses waartydens die afrigter die verhoging van lewenservaring en doelwitbereiking in die persoonlike of professionele lewe van normale, nie-kliniese kliënte fasiliteer (Grant 2003:254; Spence \& Grant 2007:186). Afrigting word ook beskou as 'n voortdurende vennootskap tussen 'n afrigter en 'n kliënt met die fokus op die aksienemende kliënt ten einde visies, doelwitte en begeertes te realiseer (McCluskey 2008:266).

Lewenstylafrigting gaan dus om 'n verhouding tussen 'n afrigter en 'n kliënt met die bereiking van persoonlike ontwikkelingsuitkomste as doel. Afrigting is dialooggebaseerd, maar aksie-georiënteerd. Dit sluit sowel 'praat' as 'doen' in. Afrigters bespoedig doelwitbereiking deur individue met die ontwikkeling en implementering van oplossings te help. Die rol van die afrigter as fasiliteerder van oplossings word beklemtoon by die aanwending van

TABEL 2: Afrigting en ander bendaderings.

\begin{tabular}{|c|c|c|}
\hline Konsep & Oorsprong & Definisie \\
\hline Leierskap & Bestuurs- en gedragswetenskappe & $\begin{array}{l}\text { Die vermoë om ander te inspireer en hulle gedrag te beïnvloed sodat hulle 'n bydrae tot die organisasie se doelwitte } \\
\text { kan lewer. }\end{array}$ \\
\hline Bestuur & Bestuurswetenskappe & $\begin{array}{l}\text { Die proses van beplanning, organisering, leiding en beheer om die organisasie se doelwitte op die effektiefste en } \\
\text { mees doeltreffende manier te bereik. }\end{array}$ \\
\hline Berading & Sielkunde & $\begin{array}{l}\text { 'n Tweerigtingverhouding tussen ' } n \text { berader en ' } n \text { individu waar die berader die individu help om hindernisse na } \\
\text { prestasie en verwesenliking te oorkom. }\end{array}$ \\
\hline Opleiding & Opvoedkunde & Voorsien vaardigheidsontwikkeling sodat werknemers meer werksdoeltreffend sal funksioneer. \\
\hline Konsultering & Bestuurswetenskappe & $\begin{array}{l}\text { 'n Proses waar 'n gespesialiseerde konsulteringsdiens aan 'n kliënt verskaf word om 'n oplossing vir 'n spesifieke } \\
\text { werkplekprobleem of -kwessie te vind. }\end{array}$ \\
\hline Mentorskap & Mitologie & $\begin{array}{l}\text { 'n Dinamiese en wedersydse verhouding in ' } n \text { werksomgewing waar ' } n \text { gevorderder en wyser ampsdraer' } n \text { minder } \\
\text { ervare persoon met ontwikkelingspotensiaal help om in spesifieke areas te ontwikkel. }\end{array}$ \\
\hline Afrigting & Sport & $\begin{array}{l}\text { Die sistematiese, beplande en direkte leiding van ' } n \text { afrigter aan ' } n \text { individu of groep om sekere vaardighede te } \\
\text { ontwikkel en wat in die werkplek vir prestasiebevordering toegepas kan word. }\end{array}$ \\
\hline
\end{tabular}

Bron: Meyer, M. \& Fourie, L., 2004, Mentoring and coaching: Tools and techniques for implementation, Knowres Publishing (Pty) Ltd., Randburg 
oplossing-gefokusde tegnieke, waartydens die kliënt sy of haar eie persoonlike sterk punte en hulpbronne benut (Spence \& Grant 2007:186).

Die veld van afrigting is jonk en multidissiplinêr van aard. Daarom kan dit ten slotte beskryf word as 'n ontluikende dissipline, waar afrigtingspesifieke teorie en bewysgebaseerde praktyk ' $n$ reuse uitdaging aan akademici, navorsers en praktisyns bied (Grant \& Cavanagh 2007b:241).

\section{Finale -'n Geïntegreerde geheel}

Die libretto is ingelei deur die overture, wat 'n kort voorstelling gebied het van die onderskeie gespreksgenote wat aan die interdissiplinêre gesprek deelgeneem het. Vier domeine is voorgestel, naamlik die praktiese teologie, middelloopbaanontwikkeling, spirituele intelligensie en lewenstylafrigting. In hierdie finale word elke deelnemende stem geïntegreer en tot ' $n$ sinvolle geheel verweef.

Die soeke na middelloopbaanontwikkeling deur spirituele lewenstylafrigting is positief aangedui en gemotiveer. Lewenstylafrigting kan leiding bied in die beantwoording van eksistensiële vrae wat in die spirituele opgesluit is. Die uitkoms beloof om toegevoegde betekenis en sinbelewing as vergestaltende komponente in 'n transformerende lewensskuif te wees.

\section{Erkenning \\ Mededingende belange}

Die outeurs verklaar dat hulle geen finansiële of persoonlike verbintenis het met enige party wat hulle nadelig kon beïnvloed in die skryf van hierdie artikel.

\section{Outeursbydrae}

Die artikel spruit uit die doktorale proefskrif 'Middelloopbaanontwikkeling deur spirituele lewenstylafrigting' van M.C.F. (Universiteit van die Vrystaat) wat onder die studieleiding van J.A.v.d.B. (Universiteit van die Vrystaat) in die Departement Praktiese Teologie voltooi is.

\section{Literatuurverywings}

Atchley, R.C. \& Barusch, A.S., 2004, Social forces \& aging: An introduction to social gerontology, 10th edn., Thomson Wadsworth, Belmont, CA.

Bachkirova, T., Cox, E. \& Clutterbuck, D., 2010, 'Introduction', in E. Cox, T. Bachkirova $\&$ D. Clutterbuck (ed.), The complete handbook of coaching, pp. 1-20, Sage Publications Ltd., London.

Betz, N.E., 2003, 'A Proactive Approach to Midcareer Development', The Counseling Psychologist 31(2), 205-211. http://dx.doi.org/10.1177/0011000002250478

Bjorklund, B.R. \& Bee, H.L., 2008, The journey of adulthood, 6th edn., Pearson Education, Inc., Upple Saddle River, NJ.

Bons-Storm, R., 1989, Hoe gaat het met jou? Pastoraat als komen tot verstaan, Kok Pharos Publishing House, Kampen.

Bown-Wilson, D. \& Parry, E., 2009, 'Career plateauing in older workers', in S.G. Baugh \& S.E. Sullivan (ed.), Maintaining focus, energy and options over the career, pp. 75-105, Information Age Publishing, Inc., Charlotte, NC.

Browning, D.S., 1991, A fundamental practical theology, Fortress Press, Minneapolis, $\mathrm{MN}$.

Carette, J. \& King, R., 2005, Selling spirituality: The silent takeover of religion, Routledge, London.

Cilliers, J., 2009, “Fides quaerens societatem': Praktiese Teologie op Soek na Sosiale Vergestalting', Tydskrif vir Geesteswetenskappe 49(4), 624-638.
Collins, G.R., 2005, Die A tot Z van berading: Die mees omvattende gids, Struik, Kaapstad.

De Haan, E., 2008, Relational coaching: Journeys towards mastering one-to-one learning, John Wiley \& Sons Ltd., Chichester.

Eby, L.T., Butts, M. \& Lockwood, A., 2003, 'Predictors of Success in the Era of the Boundaryless Career', Journal of Organizational Behavior 24, 689-708. http:// dx.doi.org/10.1002/job.214

Fourie, M.C., 2010, 'Middelloopbaan-ontwikkeling deur spirituele lewenstylafrigting', doktorale proefskrif, Departement Praktiese Teologie, Universiteit van die Vrystaat.

Geertz, C., 1980, 'Blurred Genres: The Refiguration of Social Thought', American Scholar 49, 165-179.

Giacalone, R.A., Jurkiewicz, C.L. \& Fry, L.W., 2005, 'From advocacy to science: The next steps in workplace spirituality research', in R.F. Paloutzian \& C.L. Park (eds.), Handbook of the psychology of religion and spirituality, pp. 515-528, The Guilford Handbook of the psycho
Press, New York, NY.

Giri, A.K., 2002, 'The Calling of a Creative Transdisciplinarity', Futures 34, 103-115. http://dx.doi.org/10.1016/S0016-3287(01)00038-6

Giri, A.K., 2004, Creative social research: Rethinking theories and methods, Lexington Books, Lexington VA.

Grant, A.M., 2003, 'The Impact of Life Coaching on Goal Attainment, Metacognition and Mental Health', Social Behavior and Personality 31(3), 253-264. http://dx.doi. org/10.2224/sbp.2003.31.3.253

Grant, A.M., 2006, 'A Personal Perspective on Professional Coaching and the Development of Coaching Psychology', International Coaching Psychology Review $1(1), 12-22$

Grant, A.M., 2008, ‘Personal Life Coaching for Coaches-In-Training Enhances Goal Attainment, Insight and Learning', Coaching: An International Journal of Theory, Research and Practice 1(1), 54-70.

Grant, A.M. \& Cavanagh, M. J., 2007a, 'The Goal-Focused Coaching Skills Questionnaire: Preliminary Findings', Social Behavior and Personality 35(6), 751-760. http:// dx.doi.org/10.2224/sbp.2007.35.6.751

Grant, A.M. \& Cavanagh, M.J., 2007b, 'Evidence-Based Coaching: Flourishing or Languishing?', Australian Psychology 42(4), 239-254. http://dx.doi.org/10.1080/ 00050060701648175

Grant, A.M. \& Zackon, R., 2004, 'Executive, Workplace and Life Coaching: Findings from a Large-Scale Survey of International Coach Federation Members', Internationa Journal of Evidence Based Coaching and Mentoring 2(2), 1-15.

Greenhaus, J.H., Callanan, G.A. \& Godshalk, V.M., 2000, Career management, 3rd edn., Harcourt, Inc., Boston, MA.

Greenhaus, J.H., Callanan, G.A. \& Godshalk, V.M., 2010, Career management, 4th edn., Sage Publications Inc., Thousand Oaks, CA.

Gutteridge, T.G., 1986, 'Organizational career development systems: The state of the practice', in D.T. Hall \& Associates (eds.), Career development in organizations, pp. 50-94, Jossey-Bass Publishers, San Francisco, CA.

Hall, D.T., 1996, 'Protean Careers of the 21st Century', Academy of Management Executive 10(4), 8-16. http://dx.doi.org/10.5465/AME.1996.3145315

Hamlin, R.G., Ellinger, A.D. \& Beattie, R.S., 2009, 'Toward a Profession of Coaching? A Definitional Examination of 'Coaching', 'Organization Development', and 'Human Resource Development", International Journal of Evidence Based Coaching and Mentoring 7(1), 13-38.

Hicks, D.A., 2003, Religion and the workplace: Pluralism, spirituality, leadership, University Press, Cambridge. http://dx.doi.org/10.1017/CBO9780511615474

Jung, C.G., 1933, Modern man in search of a soul, Harcourt, Brace \& World, New York, NY. PMid:16745175, PMCid:1252961

Katz, S.N., 1995, 'Do Disciplines Matter? History and the Social Sciences', Social Science Quarterly 76(4), 863-877.

Kennedy, M., 1980, The concise Oxford dictionary of music, 3rd edn., Oxford University Press, Oxford.

Kinjerski, V.M. \& Skrypnek, B.J., 2008, 'Four Paths to Spirit at Work: Journeys of Personal Meaning, Fulfillment, Well-Being, and Transcendence Through Work' The Career Development Quarterly 56, 319-329. http://dx.doi.org/10.1002/ The Career Development Qua

Klasen, N. \& Clutterbuck, D., 2002, Implementing mentoring schemes: A practical guide to successful programs, Butterworth-Heinemann, Oxford.

Lachman, M.E., 2004, 'Development in Midlife', Annual Review of Psychology 55, 305-331. http://dx.doi.org/10.1146/annurev.psych.55.090902.141521, PMid:14744218

Lester, A.D., 1995, Hope in pastoral care and counseling, Westminister John Knox Press, Louisville, KY.

Louw, D.A. \& Edwards, D.J.A., 2005, Sielkunde: 'n Inleiding vir studente in Suider-Afrika, 2de uitgawe, Heinemann Voortgesette Onderwys (Edms) Bpk, Sandton.

Louw, D.J., 1999, Pastoraat as vertolking en ontmoeting, Lux Verbi.BM (Edms) Bpk., Wellington.

Louw, D.J., 2005, Ratwerk van die menslike siel: Oor volwassenheid en lewensvaardighede, Sun Press, Stellenbosch.

Marques, J., Dhiman, S. \& King, R., 2007, Spirituality in the workplace: What it is, why it matters, how to make it work for you, Personhood Press, Fawnskin, CA.

Marques, J., Dhiman, S. \& King, R., 2009, The workplace and spirituality: New perspectives on research and practice, SkyLight Paths Publishing, Woodstock, VT.

McCluskey, C., 2008, 'A Christian-Therapist-Turned-Coach Discussing His Journey and the Field of Life Coaching', Journal of Psychology and Christianity 27(3), 266-269. 
Merriam, S.B., Caffarella, R.S. \& Baumgartner, L.M., 2007, Learning in adulthood: A comprehensive guide, 3rd edn., Jossey Bass, San Francisco, CA.

Meyer, M. \& Fourie, L., 2004, Mentoring and coaching: Tools and techniques for implementation, Knowres Publishing (Pty) Ltd., Randburg.

Miller, W.R., 2000, Integrating spirituality into treatment, American Psychological Association, Washington, DC.

Mitroff, I.I. \& Denton, E.A., 1999, 'A Study of Spirituality in the Workplace', Sloan Management Review 40, 83-92.

Mohamed, A.A., Wisnieski, J., Askar, M. \& Syed, I., 2004, 'Towards a Theory of Spirituality in the Workplace', Competitiveness Review 14(1/2), 102-107.

Müller, J.C., 1996, Om tot verhaal te kom: Pastorale gesinsterapie, Raad vir Geesteswetenskaplike Navorsing, Pretoria.

Müller, J.C., 2001, 'Therapy as Fiction Writing', Nederduitse Gereformeerde Teologiese Tydskrif 42(1/2), 64-70.

Müller, J.C., 2008, 'Postfundamentele teologie', in F. Gaum, A. Boesak \& W. Botha (reds.), Christelike kern-ensiklopedie, Lux Verbi.BM (Edms) Bpk., Wellington.

Müller, J.C., Van Deventer, W. \& Human, L., 2001, 'Fiction Writing as Metaphor for Research: A Narrative Approach', Practical Theology in South Africa 16(2), 76-96.

Orem, S.L., Binkert, J. \& Clancy, A.L., 2007, Appreciative coaching: A positive process for change, Jossey-Bass, San Francisco, CA.

Osmer, R.R., 2006, 'Toward a transversal model of interdisciplinary thinking in practical theology', in F. LeRon Shults (ed.), The evolution of rationality: Interdisciplinary essays in honor of I Wentzel van Huyssteen, pp. 327-346, Wm. B. Eerdmans Publishing Co., Grand Rapids, MI.

Osmer, R.R., 2008, Practical theology: An introduction, Wm. B. Eerdmans Publishing Co., Grand Rapids, MI.

Osmer, R.R. \& Schweitzer, F.L., 2003, 'Introduction', in R.R. Osmer \& F.L. Schweitzer (ed.), Developing a public faith: New directions in practical theology, pp. 1-11, Chalice Press, St Louis, MO.

Oxtoby, C., 1964, Wat is musiek, Tafelberg-uitgewers, Kaapstad.

Papalia, D.E., Sterns, H.L., Feldman, R.D. \& Camp, C. J., 2007, Adult development with aging, 3rd edn., McGraw-Hill Companies, Inc., New York, NY. PMCid:2267623

Raddon, R., 2005, 'Work: Overview and philosophy', in R. Raddon (ed.), Your career, your life: Career management for the information professional, pp. 3-17, Ashgate Publishing Limited, Aldershot.

Rice, D., 2007, 'Life Coaching - Can it Help Fulfilment and Happiness?', Irish Veterinary Journal 60(8), 501-503.

Robbins, S.P., 2001, Organizational behaviour, 9th edn., Prentice-Hall, Inc., Upper Saddle River, NJ.

Rogers, J., 2004, Coaching skills: A handbook, The Cromwell Press, Whiltshire.

Scholes, P.A., 1970, The Oxford companion to music, 10th edn., Oxford University Press, London.

Sherburne, C., 2008, 'Spirituality: The Beauty Secret of Aging', The LLI Review, Fall, 102-108.
Smith, N.R., 2006, Workplace spirituality: A complete guide for business leaders, Axial Age Publishing, Peabody, MA.

Spence, G.B., 2007, 'Further Development of Evidence-Based Coaching: Lessons from the Rise and Fall of the Human Potential Movement', Australian Psychologist 42(4), 255-265. http://dx.doi.org/10.1080/00050060701648142

Spence, G.B. \& Grant, A.M., 2007, 'Professional and Peer Life Coaching and the Enhancement of Goal Striving and Well-Being: An Exploratory Study', The Journal of Positive Psychology 2(3), 185-194. http://dx.doi.org/10.1080/17439760701228896

Swinton, J. \& Mowat, H., 2006, Practical theology and qualitative research, SCM Press, London.

Van den Berg, J.A., 2008, 'An Embodied Spirituality: Perspectives for a Bodily Pastoral Anthropology', Acta Theologica 28(2), 118-132.

Van den Berg, J.A., 2010, "n Autobiografiese theologia habitus - Futures Perspectives for the Workplace', Acta Theologica, suppl. ser. 13.

Van der Ven, J., 1993, Practical theology: An empirical approach, Kok Pharos Publishing House, Kampen.

Van der Walt, E.A., Du Plessis, D. \& Barker, R., 2006, 'Exploring a Spiritual Intelligence (SQ) Model of Communication to Recontextualise Differences Between Management and Employees', Communication 32(2), 264-290. http://dx.doi. org/10.1080/02500160608537973

Van Huyssteen, J.W., 2006, Alone in the world?: Human uniqueness in science and theology, The Gifford lectures, Wm. B. Eerdemans Publishing Co., Grand Rapids, MI. PMid:16645122

Van Wyk, A.G., 1997, "Theology" and Interdisciplinary Co-Operation with Other Sciences', Praktiese Teologie in Suid-Afrika 12(2), 75-86.

Vilas, S. \& Corbin, J., 2005, Coach U's essential coaching tools: Your complete practice resource, John Wiley \& Sons Inc., Hoboken, NJ. PMCid:1176462

West, W., 2000, Psychotherapy \& spirituality: Crossing the line between therapy and religion, Sage Publications Inc., London.

Whitbourne, S.K., 2007, Adult development \& aging: Biopsychosocial perspectives, 3rd edn., John Wiley \& Sons, Inc., Hoboken, NJ.

Williams, P., 2006, 'Becoming a Life Coach', American Fitness 24(4), 64-65.

Williams, P. \& Menendez, D.S., 2007, Becoming a professional life coach: Lessons from the Institute for Life Coach Training, W.W. Norton \& Company, New York, NY.

Willows, D. \& Swinton, J., 2000, 'Introduction', in D. Willows \& J. Swinton (ed.) Spiritual dimensions of pastoral care: Practical theology in a multidisciplinary context, pp. 11-16, Jessica Kingsley Publishers, London.

Wink, P. \& Dillon, M., 2002, 'Spiritual Development Across the Adult Life Course: Findings from a Longitudinal Study', Journal of Adult Development 9(1), 79-94. http://dx.doi.org/10.1023/A:1013833419122

Wolcott, J., 2001, 'Get a Life!', Christian Science Monitor 93(90), 11.

Zohar, D. \& Marshall, I., 2000, Spiritual intelligence: The ultimate intelligence, Bloomsbury, London. PMCid:3181589

Zohar, D. \& Marshall, I., 2004, Spiritual capital: Wealth we can live by, Bloomsbury, London. 